\title{
ACOPIO: Cuba's State Procurement and Distribution Agency 1
}

José Alvarez ${ }^{2}$

On October 28, 2000, U.S. President Bill Clinton signed the Trade Sanctions Reform and Export Enhancement Act (TSRA) which allowed U.S. firms to sell food and agricultural products to Cuba and other countries. However, the Cuban government did not purchase any of these products until December of 2001 following the devastating damage caused by Hurricane Michelle to important agricultural areas in November of that year.

Cuban purchases from U.S. firms amounted to $\$ 4.319$ million in 2001, \$138.635 million in 2002, and $\$ 256.9$ million in 2003. Cuba became the 35th most important food and agricultural export market for the United States in 2003, up from last (226th) in 2000. Actual purchases and pending contracts in the first-half of 2004 are at a pace to move Cuba into the top 20 most important markets of U.S. food and agricultural exports. Furthermore, because current U.S. legislation requires that all Cuban purchases from the United States must be conducted on a cash basis, the lack of credit risk associated with these sales makes Cuba one of the most attractive export markets for U.S. firms.
Anticipating changes in U.S.-Cuba trade relations, the Food and Resource Economics Department at UF/IFAS initiated a research initiative on Cuba in 1990, including a 1993 collaborative agreement with the University of Havana, which has lasted to this day. (Most of the resulting publications can be found at http://www.cubanag.ifas.ufl.edu). We reiterate that our role as investigators is to provide the best available information and analyses from which rational decisions can be made. The reports included in this series intend to address the increasing level of interest in the Cuban market for food and agricultural products among U.S. firms and to assist them in becoming more familiar with that market. The complete list of documents in this series can be found by conducting a topical search for "Cuba" at http://edis.ifas.ufl.edu, or under "Additional Information" at the end of this document.

\section{Introduction}

One of the reasons for the food scarcity in Cuba, especially that related to perishable and non-perishable agricultural product wastes, falls on Acopio, the state collection and distribution agency.

1. This is EDIS document FE484, a publication of the Department of Food and Resource Economics, Florida Cooperative Extension Service, UF/IFAS, University of Florida, Gainesville, FL. Published July 2004. Please visit the EDIS website at http://edis.ifas.ufl.edu.

The author would like to thank the University Press of Florida (http://www.upf.com) for permission to reproduce material from the book Cuba's Agricultural Sector (Alvarez, 2004).

2. José Alvarez, Professor, Department of Food and Resource Economics, Everglades Research and Education Center, Belle Glade, FL, Florida Cooperative Extension Service, UF/IFAS, University of Florida, Gainesville, FL.

The Institute of Food and Agricultural Sciences is an equal opportunity/affirmative action employer authorized to provide research, educational information and other services only to individuals and institutions that function without regard to race, color, sex, age, handicap, or national origin. For information on obtaining other extension publications, contact your county Cooperative Extension Service office. Florida Cooperative Extension Service/Institute of Food and Agricultural Sciences/University of Florida/Christine Taylor Waddill, Dean. 
This fact sheet summarizes the role of this state agency since the early days of the Cuban revolution along with its inefficiencies and reorganizations.

\section{Establishment and Philosophy}

The state procurement and distribution system dates back to 1959 when Cuban government established a mandatory structure to purchase corn as animal feed from farmers in Cuba's eastern region. The system was later expanded to cover other agricultural products and areas. By 1962, a national Acopio (collection or procurement) system, covering all agricultural products, was in place (Duyos, 1964). The result was the National Collection Unit (Unión Nacional de Acopio, UNA). With minor modifications, that system has remained in place to this day.

Acopio thus has been the official link between producers and consumers since the early years of the revolution. Throughout the years, it has become a highly centralized entity intended to collect and distribute all farm production. Production, however, could never be recorded in its totality since, as discussed in other fact sheets, it excluded on-farm consumption, bartering systems, and black market sales.

During the time period when the Cuban free farmers' markets were in existence (1980-1986), surplus production was legally sold directly to consumers. When these markets were still open, Figueroa Arbelo and García de la Torre (1984) criticized the lack of an adequate policy for Acopio prices that would allow an increase in production while, at the same time, providing incentives to the farmers to render their supplemental output to Acopio. The lack of such mechanisms led to spontaneous diversions of agricultural production. When these markets were closed the state re-assumed total control of procurement and distribution.

\section{Acopio's Reorganization}

To regain the monopoly in agricultural marketing and to improve its services, Acopio was completely reorganized after the closing of the free farmers' markets, both in terms of collection and distribution, by:
- placing the system under the Ministry of Agriculture rather than the municipal Council of People's Power where it had been until then.

- establishing the Enterprise of Selected Fruits (Empresa de Frutas Selectas), also under the Ministry of Agriculture, to purchase surplus fruits and vegetables from private farmers and agricultural production cooperatives (CPAs) and then sell them directly to the domestic and tourist markets.

- increasing the prices paid to producers, especially those paid by the newly created Enterprise of Selected Fruits, to avoid drastic decreases in farmers' incomes after the closing of the free farmers' markets in 1986 (Torres and Pérez, 1994, p. 30).

- investing in additional refrigerated trucks and warehouse facilities (Deere and Meurs, 1992).

Today, Acopio, encompassing 14 provincial enterprises, is now under the Ministry of Agriculture. Under these 14 enterprises are the municipal establishments that serve over 3,700 retail outlets distributed throughout the country (García Alvarez, 1997, p. 114; Pérez Villanueva, 2000, p. 90).

Due to the hardships resulting from the Special Period, Acopio's restructuring at the national and local levels continued during the early 1990s with the creation of a new procurement process and an increase in the number of Acopio procurement personnel (visitadores de Acopio). Multiple collection points were established in the countryside for peasants to deliver their products on a given day of the week. Deere et al. (1994, pp. 224-228) describe their interview with a Cuban official who at that time stated that the probability of an Acopio official (the cashier who pays for the crop) and an Acopio truck converging at the same point at the same time was highly unlikely.

\section{Examples of Acopio's Inefficiencies}

Acopio's performance is intertwined with productivity inefficiencies and, as such, is extremely important in any discussion of the implications of the new agricultural policies and of the problems derived 
from food rationing. The amount of evidence documenting Acopio's waste and inefficiency is appalling.

Vice-President Raúl Castro, in an unusual open letter to the Minister of Agriculture published in the daily Granma, strongly criticized the state enterprise, blaming it for the existing waste that irritates consumers. He also stated that one-fourth of the agricultural commodities intended for distribution under the state system for Havana residents in April of 1991 were rotten and had to be discarded (Raúl, 1996, p. 9A). Such problems, however, have been constantly present. Pérez Marín and Muñoz Baños (1991, p. 4), for example, estimated losses of 225 kilograms per hectare (13 kilograms per capita) in tubers, roots, vegetables, and grains left unharvested in the fields.

When evaluating the Food Program, Enríquez (1994) discusses "the limitations encountered in the commercialization process" (pp. 46-52). In addition to the illegal sale of goods in short supply, she states that the Acopio system has been characterized by a number of weaknesses practically from its inception (e.g., losses due to shipping and storage problems which reduce the quantities of good available to consumers).

Losses from an inefficient system are not only related to the collection and distribution aspects, but also to food spoilage in Acopio's warehouses. For example, a study by Hernández and Drummond (1984, p. 83) estimated that food stored in Cuban warehouses for one to three months was found to suffer losses from rodents of about $1 \%$. This loss was shown to be readily preventable with standard rodent control treatments and permanent warfarin baits. Losses have grown exponentially during the Special Period because of limitations encountered in fuel, transportation, refrigeration equipment, and other areas.

One could expand this section considerably with examples of Acopio's inefficiencies but a couple of anecdotes provided by a foreign journalist will suffice. Orozco (1993) considers Acopio the worst problem of agricultural Cuba. The first anecdote relates to one of his interviews with ANAP's President about the transportation of tomatoes to the city of Havana. He says that, "with a candor that sometimes makes one believe they are pulling your leg," the President of ANAP told him that they were trying to solve the problem "with an experiment, well, something that we are reviving." Orozco was told that the "experiment" consisted of transporting perishable products directly from the producer to the retail markets, something the Acopio had never tried doing before (p. 518). The second anecdote is an interview with the first secretary of the Cuban Communist Party in the city of Havana, who expanded on the tomato experiment. He explained that the new distribution system for tomatoes consisted of transporting the product from the farm to two collection centers from which each municipality was responsible for taking them to the government's new placitas. Orozco states that the first secretary considered the system the result of a titanic work to transport a few kilograms or tons of tomatoes a few dozen kilometers to make them available to consumers (p. 520).

\section{The Internal Debate}

Facing the economic realities of the Special Period within a process of new agricultural policies, one has to wonder about the feasibility of maintaining a system originally designed to operate within a highly centralized and subsidized agricultural sector. It did not take long for the debate to start in Cuba.

Carriazo (1994) stated that the UBPCs (cooperatives) are tied to a system of collection that is highly inefficient (p. 23). He added that, "Acopio's pricing system reveals its rigidity by not reflecting with the required speed the changes in supply, demand, quality, cost and other factors" (p. 24).

González Jordán (1995, p.1) criticized Acopio's pricing system for stimulating neither production nor sales to the state. The reason given is low prices that do not correspond with the economy's general price level.

Orlando Lugo, president of the National Association of Small Farmers (ANAP), stated that the mechanisms developed through Acopio are now obsolete and that the norms used by Acopio for 
purchases from the farmers do not respond to the present realities (García Luis, 1994, p. 5).

Some Cuban specialists have raised their voices against the current organization. Pérez Villanueva (2000, p. 91) called for the reform of a system that provides little stimuli to producers and is responsible for the large losses and low quality of products sold in retail stores. Torres and Pérez (1994, p. 42), in addition to several recommendations to improve the markets, state that one could also think in terms of the explosion in the number of commercialized chains and marketing cooperatives that could serve as intermediaries between producers and consumers, taking charge of the purchasing, transporting, cleaning, promoting, and selling of products. Such chains would not only operate in the agricultural markets, but also in supermarket chains and small businesses. This recommendation did not receive official support then nor now.

\section{A New Reorganization}

The new Acopio system established after the closing of the free farmers' markets in 1986 has not solved the multiple commercialization problems. Starting in 2000, the system is again experiencing new changes. Pagés (2001) explained how the new system supplies the placitas with fixed maximum prices in the capitol of Cuba. It combines nine agricultural enterprises with 14 municipalities in Havana. Each agricultural enterprise is assigned one or two municipalities to supply both the rationed products and the products going to over 100 placitas in Havana, which are subject to maximum prices rather than to the laws of supply and demand. This new system eliminated establishments that behaved as intermediaries between producers and distributors. (Yet another indication of the Cuban government's obsession with intermediaries.) Some officials have recognized that the new system allows products to arrive fresher to markets and provides better communication between the farmers and the municipal governments of the City of Havana province. The agricultural enterprises in Havana are in charge of collecting products from the cooperatives and farmers in their district according to the contract signed with the state. The government has started selling trucks to the best cooperatives in Havana so they can carry their products (with fixed maximum prices) directly to the placitas.

At the time Pagés' article was written (August 4, 2001), only four trucks had been sold, but more have been promised for when financial conditions permit (hardly a solution to the problem). Time will tell whether this new experiment will succeed. Previous experience seems to indicate that the new system is not enough to eliminate Acopio's problems and inefficiencies.

\section{One Final Thought}

It is obvious that the mild economic reforms of the early 1990s have not solved Cuba's food production and distribution problems. It seems even more obvious that the blame should not fall on any specific organization, but on the system itself. Excessive state intervention and control are responsible for more than four decades of food scarcity. The market has to be given an opportunity to work. If the Cuban leadership is really interested in solving the food scarcity problem, here is a policy prescription: liberate input and output markets and give total freedom to private farmers and cooperatives concerning the composition and volume of their production. Simple indeed.

\section{References}

Alvarez, José. 2004. Cuba's Agricultural Sector. Gainesville, FL: University Press of Florida.

Carriazo, George. 1994. Cambios Estructurales en la Agricultura Cubana: La Cooperativización. Economía Cubana - Boletín Informativo 18 (November): 14-29 (Centro de Investigaciones de la Economía Mundial).

Deere, Carmen Diana, and Mieke Meurs. 1992. Markets, Markets Everywhere? Understanding the Cuban Anomaly" World Development 20 (6): 825-839.

Deere, Carmen Diana, Niurka Pérez, and Ernel González. 1994. The View From Below: Cuban Agriculture in the 'Special Period in Peacetime.' Journal of Peasant Studies 21 (2): 194-234. 
Duyos, Oscar. 1964. Los Problemas Actuales del Acopio y los Precios de Compra de los Productos Agrícolas. Cuba Socialista 4 (43, March): 66-78.

Enríquez, Laura J. 1994. The Question of Food Security in Cuban Socialism. Berkeley, CA: International and Area Studies, University of California.

Figueroa Arbelo, Víctor, and Luis A. García de la Torre.1984. Apuntes Sobre la Comercialización Agrícola no Estatal. Economía y Desarrollo 83: 34-61.

García Alvarez, Anicia, Isis Mañalich Gálvez, Nieves Pico García, and Nancy A. Quiñones Chang. 1997. La Sustitución de Importaciones de Alimentos: Una Necesidad Impostergable. Segunda Parte. Cuba: Investigación Económica 3(1, January-March): 1-49.

García Luis, Julio. 1994. Nuevas Perspectivas del Desarrollo Campesino. Servicio Especial de Prensa Latina, May 27.

González Jordán, Benjamín. 1995. La Agricultura Cubana: Un Balance Crítico. Economía y Desarrollo 118 (2, December): 81-97.

Hernández, A., and D.C. Drummond. 1984. A Study of Rodent Damage to Food in Some Cuban Warehouses and the Cost of Preventing It. Journal of Stored Products 20(2): 83-86.

Orozco, Román. 1993. Cuba Roja - Cómo Viven los Cubanos con Fidel Castro. Madrid, Spain: Información y Revistas S.A. Cambio 16.

Pagés, Raisa. 2001. Más Alimentos Pero Aún Siguen Drenando el Bolsillo Familiar. Granma Internacional, August 4.

Pérez Marín, E., and E. Muñoz Baños. 1991. Agricultura y Alimentación en Cuba. La Habana: Editorial de Ciencias Sociales.

Pérez Villanueva, Omar Everleny. 2000. La Reestructuración de la Economía Cubana: El Proceso en la Agricultura. In La Ultima Reforma Agraria del Siglo - La Agricultura Cubana Entre el Cambio y el Estancamiento, edited by Hans-Jürguen
Burchardt, pp. 71-105. Caracas, Venezuela: Editorial Nueva Sociedad.

Raúl Castro Critica a Ministro por Derroche en Dura Carta Abierta. 1996. El Nuevo Herald, May 27, p. 9 A.

Torres, Cary, and Niurka Pérez.1994. Mercado Agropecuario Cubano: Proceso de Constitución.

Economía Cubana - Boletín Informativo 18 (November): 29-42 (Centro de Investigaciones de la Economía Mundial).

\section{Additional Information}

Below is a list of the fact sheets in this series on Cuban Agriculture. They can be accessed by clicking on the highlighted links:

- FE479 - Cuban Agriculture Before 1959: The Political and Economic Situations

- FE480 - Cuban Agriculture Before 1959: The Social Situation

- FE481 - Transformations in Cuban Agriculture After 1959

- FE482 - Overview of Cuba's Food Rationing System

- FE483 - The Issue of Food Security in Cuba

- FE484 - Acopio: Cuba's State Procurement and Distribution Agency

- FE485 - Antecedents of the Cuban Agricultural Policies of the 1990s

- FE486 - Chronology of Cuban Reform Policies with Emphasis on Agriculture, 1993-1995

- FE487 - Cuba's Basic Units of Cooperative Production

- FE488 - Cuba's Agricultural Markets

- FE489 - Environmental Deterioration and Conservation in Cuban Agriculture 
- FE490 - The Potential Correlation between

Natural Disasters and Cuba's Agricultural

Performance 